\title{
Temporal Analysis of Ozone and Nitrogen Oxides Fluctuations at Pasir Gudang, Malaysia
}

\author{
Norrimi Rosaida Awang ${ }^{1, a},{ }^{*}$ Nor Azam Ramli ${ }^{2, b}$, Ahmad Shukri Yahaya ${ }^{3, c}$ \\ ${ }^{1,2,3}$ Clean Air Research Group, School of Civil Engineering, Engineering Campus, Universiti Sains \\ Malaysia, 14300 Nibong Tebal, Penang, MALAYSIA. \\ anorrimirosaida@gmail.com, bceazam@usm.my, cshukri@usm.my
}

Keyword: Annual fluctuations, monthly fluctuations, time series plot, nitric oxide, nitrogen dioxide

\begin{abstract}
Ozone $\left(\mathrm{O}_{3}\right)$ and nitrogen oxides $\left(\mathrm{NO}_{\mathrm{x}}\right)$ are closely related in the atmosphere. In ambient air, these pollutants always fluctuated depending on their emission sources and meteorological influences. The paper is aims to gain insight understanding of the monthly temporal variation of $\mathrm{O}_{3}$ and $\mathrm{NO}_{\mathrm{x}}$ concentrations to enable proper control strategies against these pollutants. One-year monitoring records from $1^{\text {st }}$ January to $31^{\text {st }}$ December 2009 of $\mathrm{O}_{3}$ and $\mathrm{NO}_{\mathrm{x}}$ at Pasir Gudang, were obtained from Department of Environmental Malaysia. Temporal analysis of $\mathrm{O}_{3}$ and $\mathrm{NO}_{\mathrm{x}}$ concentration fluctuation during annual and monthly were assessed using time series and scatter plots. The annual variations of $\mathrm{O}_{3}$ concentrations were negatively correlated with annual variation of $\mathrm{NO}$ and $\mathrm{NO}_{2}$ concentrations. Results suggest that $\mathrm{O}_{3}$ concentration are higher than $\mathrm{NO}$ and $\mathrm{NO}_{2}$ especially in May 2009. However, zero exceedences were recorded in the studied period for all pollutants against the Malaysia Ambient Air Quality Guidelines.
\end{abstract}

\section{Introduction}

Ozone $\left(\mathrm{O}_{3}\right)$ and nitrogen oxides $\left(\mathrm{NO}_{\mathrm{x}}\right)$ are important compounds in atmospheric chemistry. At the ground level, ozone is one of the significant air pollutants and always relates with degrading air quality especially in urban areas. High ozone levels can potentially affected human health, plant species, various natural materials, and manufactured goods [1]. Ground level $\mathrm{O}_{3}$ is produced by series of chemical reaction of the main precursors $\left(\mathrm{NO}_{\mathrm{x}}\right.$ and $\left.\mathrm{VOC}_{\mathrm{s}}\right)$ that were anthropogenic emitted in the ambient air with ultraviolet radiation that act as catalyst to the reactions [2].

$\mathrm{NO}_{\mathrm{x}}$ is produced when fuel is burned at high temperature and the primary sources of $\mathrm{NO}_{\mathrm{x}}$ are any human activities, which associated with burning fuels. The main sources of $\mathrm{NO}_{\mathrm{x}}$ came from fossil fuel combustion from either industrial and vehicular, biomass burning, microbial activity in soils, and lightning [2]. In the presence of sunlight, $\mathrm{NO}$ is generated by photolysis of $\mathrm{NO}_{2}$ but it will oxidized by $\mathrm{O}_{3}$ to regenerated $\mathrm{NO}_{2}[1,3]$. Photolysis of $\mathrm{NO}_{2}$ created atom $\mathrm{O}$ that will react with molecule $\mathrm{O}_{2}$ that already existed in the atmosphere to create $\mathrm{O}_{3}$. The destruction of $\mathrm{O}_{3}$ will happen when it is reacted with $\mathrm{NO}$ to produce $\mathrm{NO}_{2}$. Ghazali [1] regarded the $\mathrm{NO}_{2}$ photolysis and $\mathrm{NO}$ titrations are the main chemical reactions that controlling the formations and destruction of the ground level ozone. These reactions also directly influence by meteorological variability such as temperature, solar radiation, wind speed and direction as well as the availability of the precursors sources $[2,3,4]$.

Reduction in $\mathrm{NO}_{\mathrm{x}}$ emission will tremendously effected the $\mathrm{O}_{3}$ concentration vice versa. As levels of $\mathrm{O}_{3}$ and $\mathrm{NO}_{x}$ are inextricably linked, any changes in $\mathrm{O}_{3}$ levels may indicated the effectiveness of local $\mathrm{NO}_{\mathrm{x}}$ emissions control [3]. The selection of Pasir Gudang is made based on the growth of the area regarding the populations, traffic density, shipping and industrial activities. Majority of air pollution studies in Malaysia focusing in Klang Valley [1, 4, 5]. It is therefore necessary to gain insight into the $\mathrm{O}_{3}$ and $\mathrm{NO}_{x}$ relationship in the atmosphere at Sourthern region of Peninsular Malaysia. The paper, the fluctuational behavior of ozone $\mathrm{O}_{3}$ and $\mathrm{NO}_{\mathrm{x}}$ were analyzed temporally during annual and monthly. The rest of the temporal analysis is reported elsewhere. 


\section{Site description}

The dispersion and dilution of air pollution are directly influenced by local attribution such as meteorological condition as well as the location of the monitoring stations. The monitoring station was established at Sekolah Menengah Kebangsaan Pasir Gudang, Pasir Gudang (Fig. 1). Pasir Gudang was located at Johor, which is the southern state of Peninsular Malaysia. The monitoring station was established and operated by Department of Environmental, Malaysia to monitor any significant changes in the ambient air quality. Pasir Gudang is one of the Johor's districts infamous with Pasir Gudang's Port. The major industries that were governing Pasir Gudang economy were transportation and logistics, shipyard industries, petrochemical industries and oil palm storage and distribution. Pasir Gudang Port was the third busiest port in Malaysia after Klang Port and Penang Port. In 2010, Pasir Gudang Port handled about 28 million tons of cargo and received nearly 5000 international and local ships [6]. Malaysia Statistical Department (2010) reported that during 2010 census the number of Pasir Gudang populations is approximately 43,000 persons. The growth of the town indirectly degrading the air quality status at Pasir Gudang due increasing anthropogenic emissions. Climatically, Pasir Gudang as the rest of Johor state experienced tropical monsoon with uniform temperature throughout the year an average temperature is ranging from $24^{\circ} \mathrm{C}$ to $32^{\circ} \mathrm{C}$ [7].

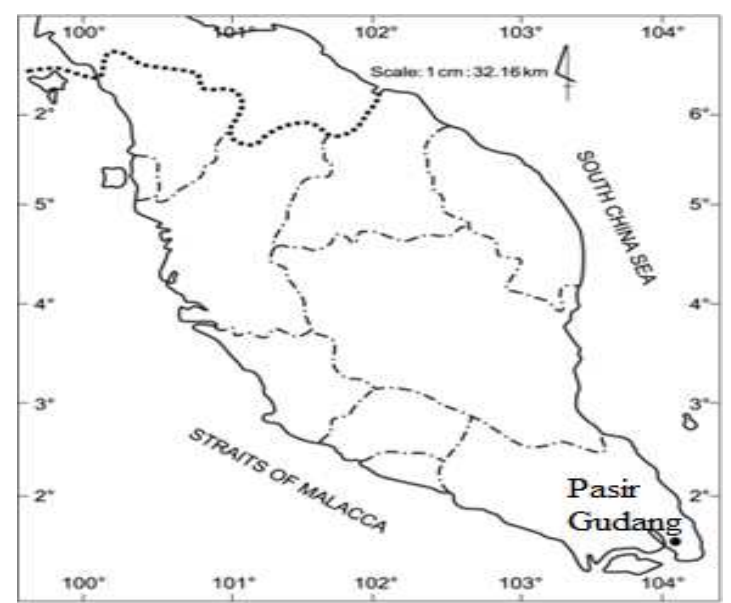

Fig 1 Location of Pasir Gudang (N01 28.225 , E103 $\left.{ }^{\circ} 53.637\right)$ in Peninsular Malaysia

\section{$\mathrm{O}_{3}$ and $\mathrm{NO}_{\mathrm{x}}$ monitoring records and measurement techniques}

One year hourly continuously monitoring records of $\mathrm{O}_{3}, \mathrm{NO}$, and $\mathrm{NO}_{2}$ were obtained from Department of Environmental Malaysia (DoE) from $1^{\text {st }}$ January to $31^{\text {st }}$ December 2009 . The record is regularly subjected to standard quality control processes and quality assurance procedures by the DoE [8], the quality controlled procedures were followed the international standards outlined by United State Environmental Protection Agency (USEPA) [11]. Hourly $\mathrm{O}_{3}$ concentrations monitoring samples were collected using UV Absorption Ozone Analyzer Model 400A which is a microprocessor controlled analyzer [8] based on the Beer-Lambert law in order to measure law ranges of $\mathrm{O}_{3}$ the ambient air or gaseous media [1]. Ambient $\mathrm{O}_{3}$ molecule were detected based on internal electronic resonance of $\mathrm{O}_{3}$ molecule using absorption of $254 \mathrm{~nm}$ UV light that were emitted from internal mercury lamp [9]. Samples of hourly and daily $\mathrm{NO}_{\mathrm{x}}\left(\mathrm{NO}, \mathrm{NO}_{2}\right)$ concentrations were collected using chemiluminescent $\mathrm{NO} / \mathrm{NO}_{2} / \mathrm{NO}_{\mathrm{x}}$ Analyzer Model 200A which is an EPA approved method. Ghazali [1] reported that, the analyzer were applying the chemiluminescent detection principle to detect the $\mathrm{NO}_{\mathrm{x}}$ concentration in the ambient air coupled with microprocessor technology to enhance the pollutants monitoring ability. The usage of microprocessor technologies in the analyzer provides sensitivity, stability and ease to be use in a continuous monitoring environment [10]. 


\section{Temporal analysis of annual and monthly fluctuations of $\mathrm{O}_{3}$ and $\mathrm{NO}_{\mathrm{x}}$ concentrations}

It is unarguable that $\mathrm{NO}$ and $\mathrm{NO}_{2}$ plays the most significant role in formations and destructions of $\mathrm{O}_{3}$ at ground level $[1,2,3]$. Fig. 2 showed the scatter plots of daily average of $\mathrm{O}_{3}$ variations against $\mathrm{NO}$ and $\mathrm{NO}_{2}$ concentrations. Since, $\mathrm{NO}_{2}$ and $\mathrm{NO}$ concentrations acts as the precursors to $\mathrm{O}_{3}$, it is expected that $\mathrm{O}_{3}$ variations to be negatively correlated with variations in $\mathrm{NO}_{2}$ and $\mathrm{NO}$ concentrations. Weak correlations coefficients $\left(\mathrm{R}^{2}\right)$ is obtained from $\mathrm{O}_{3}$ and $\mathrm{NO}_{2}(-0.364)$, while for the relationship between $\mathrm{O}_{3}$ and $\mathrm{NO}$ is slightly higher at -0.424 . During the photochemical reactions of $\mathrm{O}_{3}$ formations, molecule of $\mathrm{NO}_{2}$ is react with solar radiation produced atom of oxygen, which is later reacted with oxygen molecule producing $\mathrm{O}_{3}$ molecule $[1,3]$. Meanwhile, reactions between $\mathrm{O}_{3}$ and $\mathrm{NO}$ will destroying $\mathrm{O}_{3}$ and reproducing $\mathrm{NO}_{2}$. The inter-conversion between $\mathrm{O}_{3}, \mathrm{NO}_{2}$ and $\mathrm{NO}$ is can be well illustrated by diurnal plot ( 24 hour), however, the result is presented elsewhere.
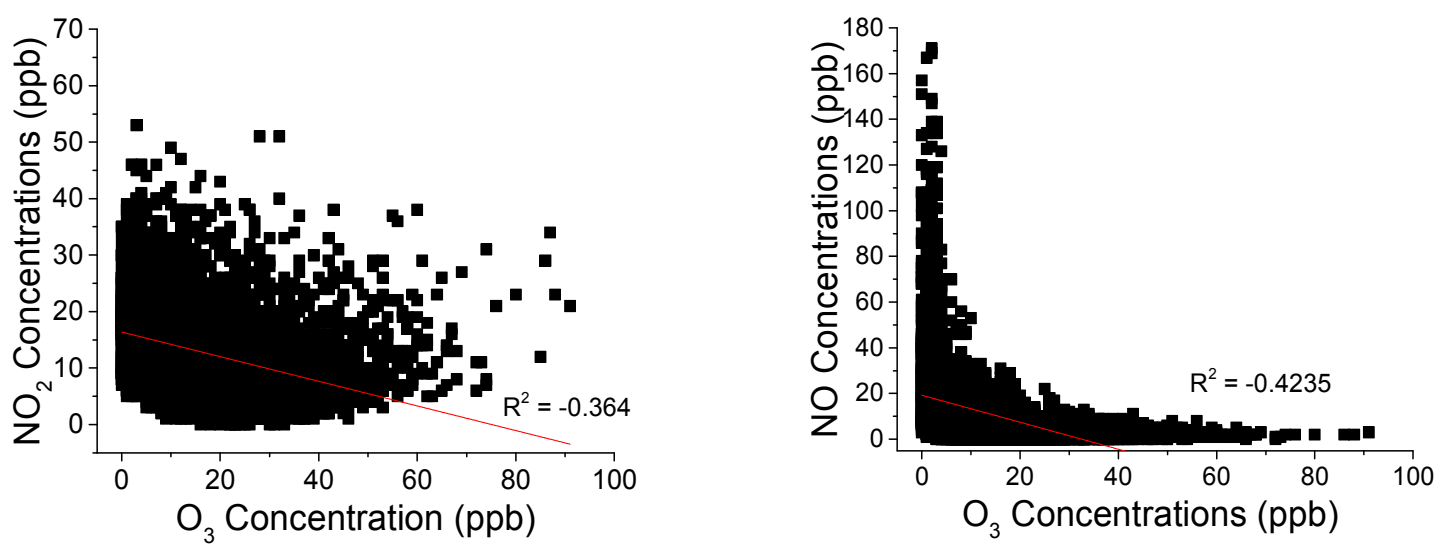

Fig 2 Scatter plots of $\mathrm{O}_{3}$ variations against $\mathrm{NO}_{2}$ and $\mathrm{NO}$ concentrations

Annual maximum concentrations of $\mathrm{O}_{3}, \mathrm{NO}$ and $\mathrm{NO}_{2}$ in Pasir Gudang are analyzed using time series plots as shown in Fig. 3. The results suggested that $\mathrm{O}_{3}, \mathrm{NO}$ and $\mathrm{NO}_{2}$ were fluctuated throughout the year and relatively high concentrations were observed during second and third quarter of the year (April- September). Figuratively, Pasir Gudang experienced more severe NO pollutions compared to $\mathrm{O}_{3}$ and $\mathrm{NO}_{2}$ pollutions. Han [3] reported that vehicular emissions is the main contributors towards NO pollution and it is reported by Ministry of Transport Malaysia [6] the total number of registered vehicle in Johor is approximately 2.7 million in year 2010. Noticeably, all pollutants were at minimal concentrations during the early and the end of the year compared to during the mid of the year. Several distinct peaks of $\mathrm{O}_{3}$ concentrations were observed throughout the year especially during March to May, which is coincided with increasing trends in $\mathrm{NO}$ and $\mathrm{NO}_{2}$ concentrations. However, these peaks concentrations not rise beyond MAAQG levels of $100 \mathrm{ppb}$ for $\mathrm{O}_{3}$ and $170 \mathrm{ppb}$ for $\mathrm{NO}$ and $\mathrm{NO}_{2}$ for 1-hor averaging period. The means of maximum concentrations of $\mathrm{O}_{3}, \mathrm{NO}_{2}$ and $\mathrm{NO}$ in Pasir Gudang in 2009 are $36.13 \mathrm{ppb}, 24.80 \mathrm{ppb}$ and 50.96, respectively. 


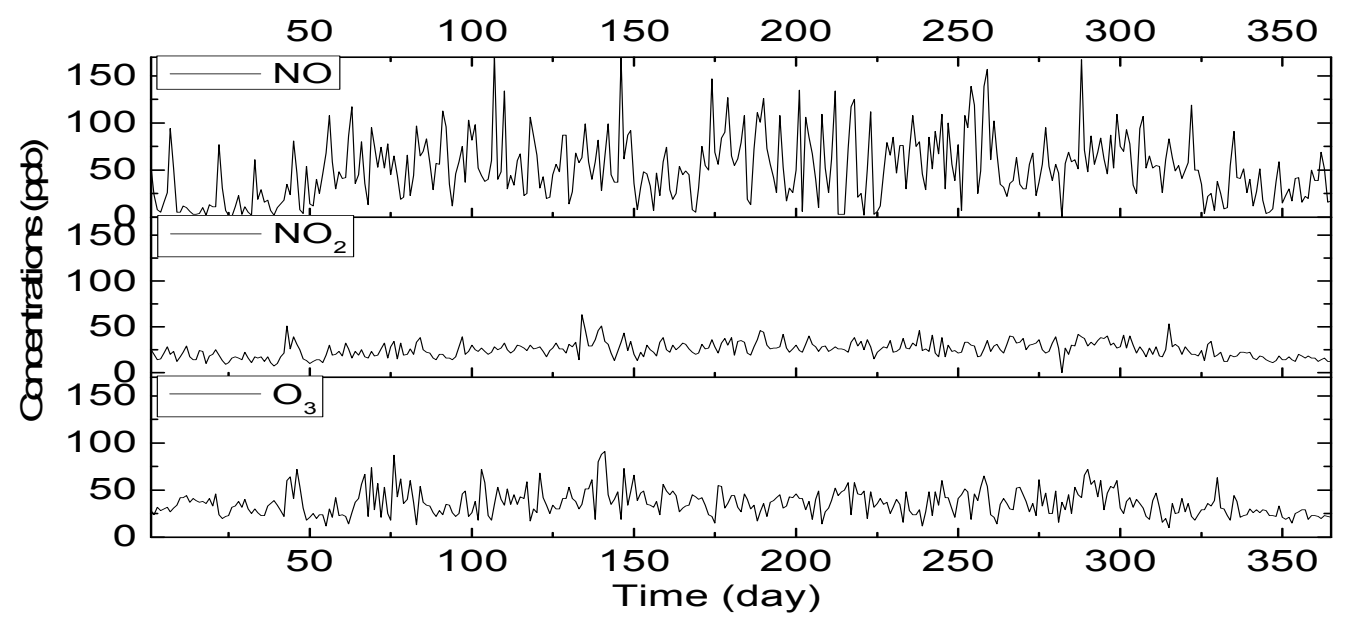

Fig 3 Time series plot of daily average $\mathrm{O}_{3}, \mathrm{NO}$, and $\mathrm{NO}_{2}$ concentrations
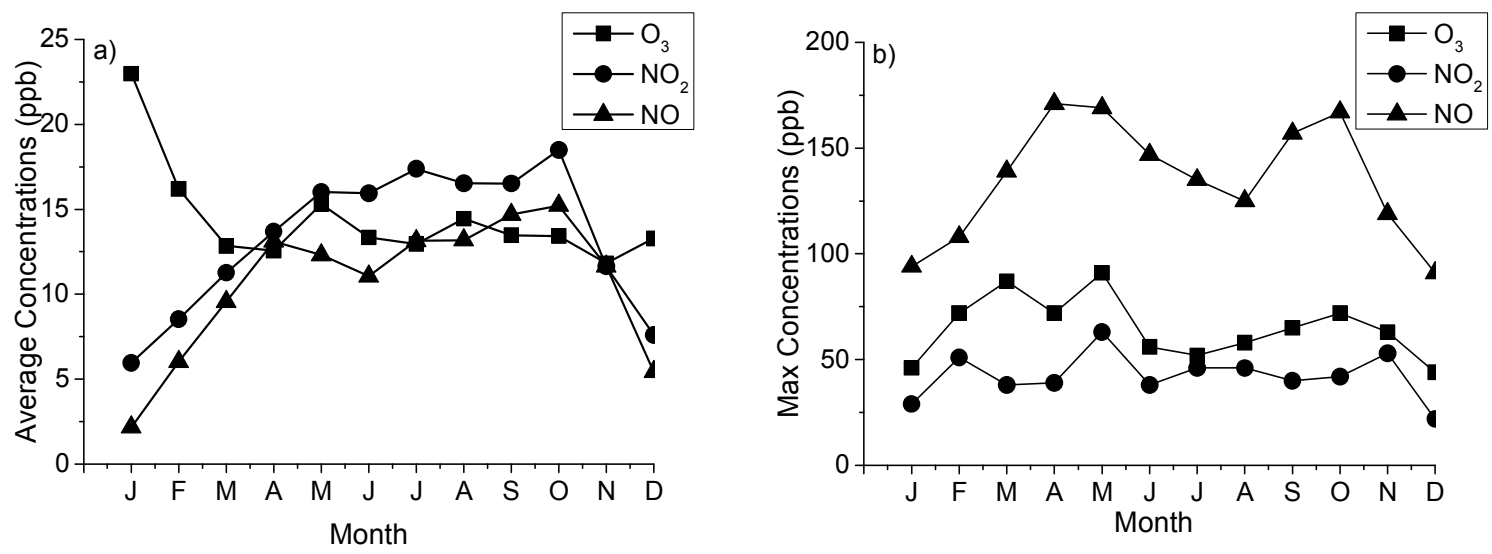

Fig 4 Monthly temporal variations concentrations of $\mathrm{O}_{3}, \mathrm{NO}$, and $\mathrm{NO}_{2}$; a) average; b) maximum

Fig. 4 illustrated the plot of monthly average and maximum of $\mathrm{O}_{3}$ and $\mathrm{NO}_{\mathrm{x}}$ concentrations in 2009. From the average plot, January recorded the highest in $\mathrm{O}_{3}$ concentration $(23 \mathrm{ppb}$ ) followed by February $(16.2 \mathrm{ppb})$. However, the highest average concentrations for $\mathrm{NO}$ and $\mathrm{NO}_{2}$ were recorded on July and October with $17.4 \mathrm{ppb}$ and $15.22 \mathrm{ppb}$, respectively. Results also exhibits that, the lowest monthly average concentration recorded on November for $\mathrm{O}_{3}(11.8 \mathrm{ppb})$ and on December for both $\mathrm{NO}(5.42 \mathrm{ppb})$ and $\mathrm{NO}_{2}(7.6 \mathrm{ppb})$ concentration. Meanwhile, based on Fig. 4(b) the highest maximum concentrations of $\mathrm{O}_{3}, \mathrm{NO}_{2}$ and $\mathrm{NO}$ is all recorded on May with $91 \mathrm{ppb}, 63 \mathrm{ppb}$ and 169 $\mathrm{ppb}$, respectively. It is also observed, lower maximum concentration of all pollutants during December and January which most probably induced by monsoonal effect. According to Toh [11], there are two major monsoonal period occurs in Malaysia which are North East Monsoon (November to March) and South west Monsoon (June to September) accompanied by two intermonsoon periods. Heavy rainfall, which always associated with North East Monsoon, may contribute to the reductions of the $\mathrm{O}_{3}$ and $\mathrm{NO}_{\mathrm{x}}$ concentrations in the atmosphere. Increasing in intensity of the rainfall will be promoting wet deposition of air pollution molecule in ambient air, thus reducing the pollution concentration $[3,11]$. All pollutant especially ozone shall have scouring effect due to rainfall and $\mathrm{PM}_{10}$ will be effected by wet deposition. Scavenging of air pollutants in ambient air also can be triggered by chemical reactions such as NO titration as well as dispersion and transport of the pollutants by winds $[2,3,4,11]$.

\section{Conclusion}

The result demonstrated that $\mathrm{NO}$ is more prominent air pollutant in Pasir Gudang compared to $\mathrm{O}_{3}$ and $\mathrm{NO}_{2}$. However, since $\mathrm{O}_{3}$ formation was controlled by $\mathrm{NO}_{x}$ concentration, $\mathrm{O}_{3}$ can also plays significant role towards air pollution status in Pasir Gudang. This study proved that, annual 
variations in $\mathrm{O}_{3}$ concentration is negatively correlated with annual $\mathrm{NO}_{2}$ and $\mathrm{NO}$. Even though, there are several spikes were observed on the pollution annual time series plots, there are zero exceedences of the guidelines limit were recorded. The maximum monthly $\mathrm{O}_{3}$ concentration with $91 \mathrm{ppb}$ is observed on May 2009, while the monthly maximum of $\mathrm{NO}$ and $\mathrm{NO}_{2}$ concentrations are $169 \mathrm{ppb}$ and $63 \mathrm{ppb}$, respectively. Heavy rainfall that is associated with North East Monsoon during November to March every year promoting pollutants scouring effect, hence $\mathrm{O}_{3}$ and $\mathrm{NO}_{\mathrm{x}}$ concentrations during the periods is significantly lower than the rest of the year.

\section{Acknowledgement}

The authors acknowledge the Department of Environmental, Malaysia for proving the air pollutions monitoring records. This study was funded by Universiti Sains Malaysia under grant $1001 \backslash$ PAWAM $\backslash 811206$. Thanks to Ministry of Higher Education Malaysia for providing financial support under MyBrain Program to carry out this study.

\section{References}

[1] Ghazali, N.A., N.A. Ramli, A.S. Yahaya, N.F.F.M.D. Yusof, N. Sansuddin, and W.A. Al Madhoun. "Transformation of Nitrogen Dioxide into Ozone and Prediction of Ozone Concentrations Using Multiple Linear Regression Techniques." Environmental Monitoring and Assessment 165, no. 1 (2010): 475-89.

[2] Seinfeld, John H, and Spyros N Pandis. Atmospheric Chemistry and Physics: From Air Pollution to Climate Change. John Wiley \& Sons, 2006.

[3] Han, Suqin, Hai Bian, Yinchang Feng, Aixia Liu, Xiangjin Li, Fang Zeng, and Xiaoling Zhang. "Analysis of the Relationship between $\mathrm{O}_{3}, \mathrm{NO}$ and $\mathrm{NO}_{2}$ in Tianjin, China." Aerosol Air Quality Research 11 (2011): 128-39.

[4] Clapp, Lynette J, and Michael E Jenkin. "Analysis of the Relationship between Ambient Levels of $\mathrm{O}_{3}, \mathrm{NO}_{2}$ and $\mathrm{NO}$ as a Function of $\mathrm{NO}_{\mathrm{x}}$ in the UK." Atmospheric Environment 35, no. 36 (2001): 6391-405.

[5] Ahamad, Fatimah, Mohd Talib Latif, Rosy Tang, Liew Juneng, Doreena Dominick, and Hafizan Juahir. "Variation of Surface Ozone Exceedance around Klang Valley, Malaysia." Atmospheric Research 139 (2014): 116-27.

[6] Malaysia, Ministry of Transport. "Transport Statistics 2012." Putrajaya, Malaysia, 2012.

[7] MMD, Malaysia Meteorological Department. "General Climate of Malaysia." Ministry of Science, Technology and Innovation, http://www.met.gov.my/index.php?option=com_content\&task=view\&id=75\&Itemid=1089

[8] Mohammed, Nurul Izma, Nor Azam Ramli, and Ahmad Shukri Yahya. "Ozone Phytotoxicity Evaluation and Prediction of Crops Production in Tropical Regions." Atmospheric Environment 68 (2012): 243-49.

[9] Teledyne. "Model 200a Nitrogen Analyzer." San Diego, California: Teledyne Instruments, 2005.

[10] Teledyne. "Model 400a Ozone Analyzer." San Diego, California: Teledyne Instruments, 1999.

[11] Toh, Ying Ying, Sze Fook Lim, and Roland von Glasow. "The Influence of Meteorological Factors and Biomass Burning on Surface Ozone Concentrations at Tanah Rata, Malaysia." Atmospheric Environment 70 (2013): 435-46. 